\title{
Sediment Yields from Small Rangeland Watersheds in Western South Dakota
}

\author{
CLAYTON L. HANSON, H. G. HEINEMANN, A. R. KUHLMAN, AND J. W. \\ NEUBERGER
}

Highlight: Sedimentation studies were made between 1958 and 1969 on stock water reservoirs to determine sediment yields from rangeland watersheds on two soil textural groups of western South Dakota. Watersheds having fine-textured soils had a mean annual sediment yield of 3.47 tons per acre, while watersheds with medium-textured soils had a mean annual sediment yield of 1.03 tons per acre. The average sediment volume-weight was 62 and $81 \mathrm{lb} / \mathrm{ft}^{3}$ for the reservoirs on watersheds with fine-and medium-textured soils, respectively.

Reliable sediment yield estimates are necessary for planning efficient use and management of the water resources within any watershed. On the rangeland watersheds of the Northern Great Plains, numerous stock water reservoirs have been constructed to store water for livestock. Many of these reservoirs have drainage areas of less than 1 square mile. The rate at which sediment is deposited in reservoirs determines, to a large extent, future reservoir design criteria and the estimated period of reservoir usefulness. Information on sediment yields is also important in the design and maintenance of water-spreading systems, stream channels, irrigation canals and ditches, road culverts and drainage ditches, etc. where sediment-laden runoff water must be controlled.

Limited runoff data from small range-

The authors are agricultural engineer, U.S. Department of Agriculture, Rapid City, South Dakota; research hydraulic engineer, U. S. Dep. Agr., Columbia, Missouri; botanist, U. S. Dep. Agr., Newell, South Dakota; and deputy assistant secretary, Water and Power Resources, U. S. Department of the Interior, Washington, D.C., respectively.

The research is a contribution from the Northern Plains and Corn Belt Branches, Soil and Water Conservation Research Division, Agricultural Research Service, U. S. Dep. Agr., and the South Dakota Agricultural Experiment Station. Approved for publication by the director, Agricultural Experiment Station, South

Dakota State University, Brookings, South

Dakota, Journal Series No. 1040.

Manuscript received March 24, 1972. land watersheds are available, but there is a dearth of sedimentation data upon which to base the design of structural works for the conservation, development, and control of rangeland water resources. It is the purpose of this paper to make available pertinent, preliminary sedimentation findings from watershed studies in northwestern South Dakota. The reservoirs included in this study are located in the medium- and fine-textured soil groups common in the Northern Great Plains.

During 1957, the Agricultural Research Service, the Soil Conservation Service, and the South Dakota Agricultural Experiment Station selected a number of expertmental watersheds where hydrologic and sedimentation studies could be made with results that would apply to surrounding areas (Fig. 1). These rangeland watersheds, with drainage areas of from 30 to 1,110 acres, are located in Butte and Meade counties, South Dakota. Some watersheds are underlain by interbedded Fox Hills and Hell Creek geologic formations and some by Picrre Shale. Medium-textured soils of the TwilightAbsher and Sorum association prevail in the Fox Hills-Hell Creek areas (U. S. Department of Agriculture, 1970). Finetextured soils of the Winler-Lismas and Pierre-Kyle associations are most common in the Pierre Shale areas.

Precipitation in the Northern Great Plains is often limited, highly variable, and sporadic. For example, the 58-year average annual precipitation at the Newell Field Station at Newell, S. Dak. is 15.47 inches, but the annual precipitation has ranged from 6.6 to 28.0 inches (Spuhler et al., 1968). At the Newell Field Station, the average annual snowfall of 21.1 inches accounts for approximately $15 \%$ of the annual precipitation. March has an average snowfall of 4.7 inches, which is the most for any one month.

Annual precipitation during the study varied greatly, with the precipitation from 1957 to 1961 being only about two-thirds of normal. Precipitation at the

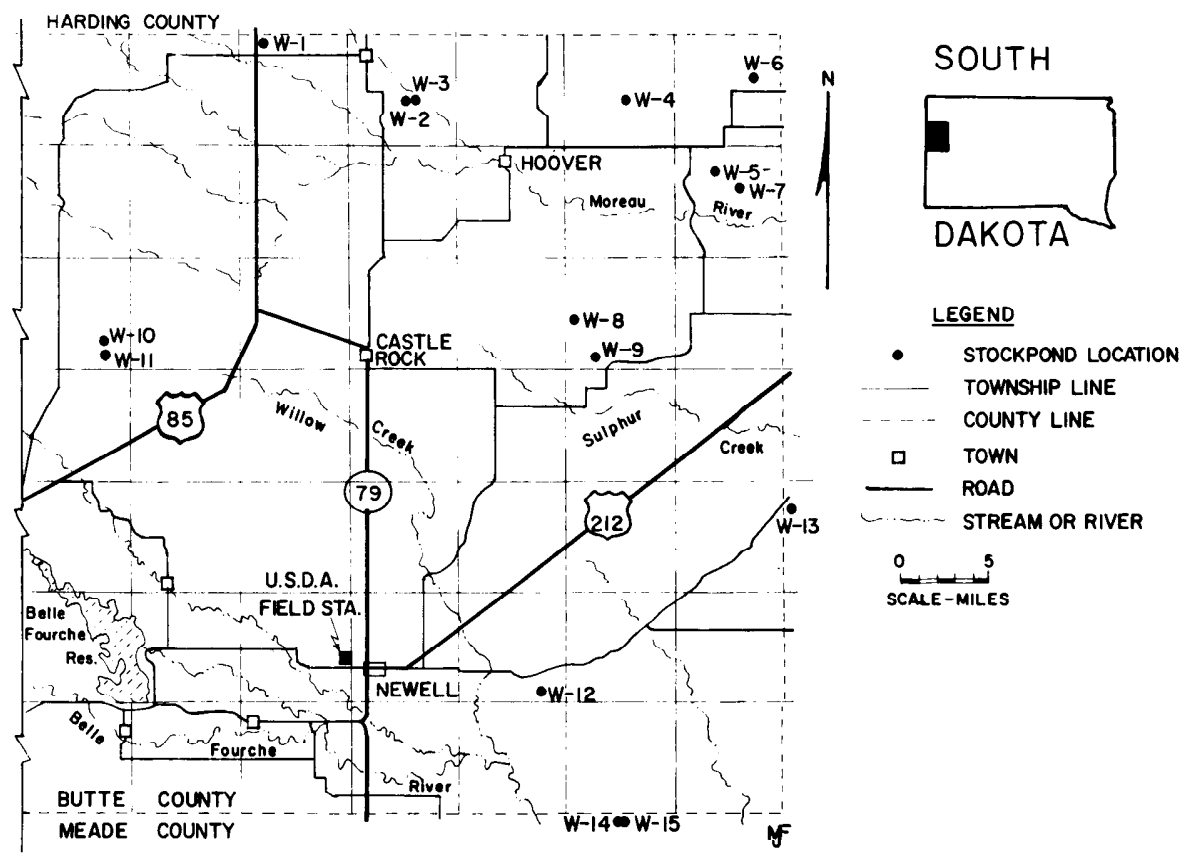

Fig. 1. Location map. 
Newell Field Station was almost 23 inches in 1962; from 1963 to 1967 , the annual precipitation was about normal. However, even during the drought years of 1957 to 1961, two high-intensity storm events occurred which amounted to 2.15 inches in $1 / 2$ hour and 3.25 inches in 1-3/4 hours. These two events equaled or exceeded the 100-year frequency as computed by the U. S. Weather Bureau (Hershfield, 1961). Such extreme variations in rainfall amount and intensity require long periods of record to establish precipitation-runoff-sediment yield relationships to be used for predicting future runoff and sediment yield.

\section{Procedure}

The sediment yields presented here were obtained from 15 watersheds on which stock water reservoirs (Fig. 2) were constructed several years before this study. Because of the difficulty in obtaining representative suspended sediment samples from the short-duration runoff events, reservoir sediment accumulation provided the only practical method of measuring sediment yields from small watersheds at remote locations in the area. Watersheds were selected on the basis of having a reservoir that could store one or more inches of runoff. Therefore, the frequency of spillway flow would be low, and reservoir trap efficiency for sediment accumulation would be high.

Table 1 lists the watershed area, slope, and range site characteristics of the watersheds on each of the medium- and finetextured soils. The percentage of watershed area in each slope group and range site was determined according to methods standardized by the Soil Conservation Service (Dyksterhuis, 1949).

A variation (Heinemann and Dvorak,

1965) of the standard reservoir sedimentation survey (Gottschalk, 1952) was used in most cases. In this variation, a base line was established along one side of the reservoir, and all main stem ranges extend perpendicularly from this base line across the reservoir. The base line was established by transit and chaining the distance between ranges. To facilitate future resurveys, many of the range ends along the base line, the instrument points, and benchmarks are referenced and permanently monumented.

For those reservoirs having an accumulation of sediment deposited before the first survey, the sediment thickness was determined with a spud and sounding pole. Numerous samples of the sediment were taken throughout the depth and extent of the deposit to determine sediment volume-weight and particle-size distribution. These data, when combined with the sediment volume, made possible the computation of sediment yield from the contributing area above each reser- voir.

\section{Findings and Discussion}

Original reservoir capacity to spillway, volume-weight of the deposited sediment, sediment yield, and loss of reservoir capacity are shown in Table 2. To illustrate the variations in sediment yields from these rangeland watersheds, the data are grouped by the two soil texture classifications.

The average sediment yield from the six fine-textured soil watersheds was 3.47 tons/acre/year, and the average yield from the nine medium-textured soil watersheds was 1.03 tons/acre/year. This comparison has some correlation with the runoff data collected from 1958-1969, which show an average annual runoff from the fine-textured watersheds of about 1.5 inches and the runoff from the medium-textured watersheds of about 0.6 inch. The sediment yields, in tons/

Table 1. Rangeland watershed area (acres), total vegetal cover (lb/acre, oven-dry), slope (\%), and range site groups (\%).

\begin{tabular}{|c|c|c|c|c|c|c|c|c|c|c|c|c|c|c|c|}
\hline \multirow[b]{2}{*}{ Item } & \multicolumn{9}{|c|}{ Medium-textured soils } & \multicolumn{6}{|c|}{ Fine-textured soils } \\
\hline & $\mathrm{W}-1^{2}$ & W-2 & W-3 & W-4 & W-5 & W-6 & W-7 & W-8 & W-9 & W-10 & W-11 & W-12 & W-13 & W-14 & W-15 \\
\hline Drainage area & 1110 & 115 & 90 & 105 & 46 & 30 & 160 & 160 & 815 & 280 & 160 & 90 & 160 & 35 & 115 \\
\hline Vegetal cover in $1960^{1}$ & $1740^{3}$ & 1984 & 2344 & 2869 & 3409 & 2966 & 2394 & 3306 & 2686 & 732 & 599 & 828 & 1516 & 485 & 1100 \\
\hline \multicolumn{16}{|l|}{ Slope groups } \\
\hline $0-3$ & 24 & 21 & 10 & 8 & & 59 & - & 8 & 8 & 1 & - & 10 & 12 & - & 19 \\
\hline $3-9$ & 73 & 40 & 70 & 40 & 89 & 31 & 80 & 50 & 21 & 27 & 61 & 25 & 81 & 97 & 81 \\
\hline $9-18$ & 2 & 19 & 20 & 42 & 11 & 8 & 20 & 17 & 33 & 20 & 27 & 65 & 5 & 3 & - \\
\hline \multirow{2}{*}{\multicolumn{16}{|c|}{ Range site groups }} \\
\hline & & & & & & & & & & & & & & & \\
\hline Sandy & 66 & & 3 & 22 & 67 & 29 & 39 & 1 & 6 & - & - & - & - & - & - \\
\hline Silty & 7 & 44 & 50 & 28 & 3 & 5 & - & 26 & 9 & - & - & - & - & - & - \\
\hline Pan spots & 20 & 14 & 15 & 18 & 19 & 42 & 23 & 21 & 15 & 1 & & 6 & 7 & - & 18 \\
\hline Shallow & 5 & 23 & 26 & 21 & 11 & 15 & 35 & 22 & 29 & 53 & 24 & 73 & 3 & 4 & 1 \\
\hline Thin breaks & - & 15 & - & - & - & - & - & 19 & 27 & - & - & - & - & - & - \\
\hline Clayey & - & - & - & - & - & & - & - & - & - & - & - & 79 & 96 & 81 \\
\hline Dense clay & - & - & - & - & - & - & - & - & - & 46 & 46 & 21 & - & - & - \\
\hline Saline upland & - & - & - & - & - & - & - & - & - & - & 30 & - & 2 & - & - \\
\hline Misc. other & 2 & 4 & 6 & 11 & - & 9 & 3 & 11 & 14 & - & - & - & 9 & - & - \\
\hline
\end{tabular}

${ }^{1}$ Includes live vegetation, standing dead vegetation and mulch.

${ }^{2} 40$ percent of watershed had been plowed but had been planted to grass prior to the establishment of this study.

${ }^{3} 1961$ vegetal cover on watershed $\mathrm{W}-1$. 
Table 2. Rangeland watershed original reservoir capacity (acre foot), sediment volume (acre foot), sediment volume weight (lb/ft ${ }^{3}$ ), sediment yield (tons/acre/yr) and loss of reservoir capacity (acre foot $/ \mathrm{mi}^{2} / \mathrm{yr}$ ).

\begin{tabular}{|c|c|c|c|c|c|c|c|c|c|c|c|c|c|c|c|c|}
\hline \multirow[b]{2}{*}{$\begin{array}{l}\text { Watershed } \\
\text { number }\end{array}$} & \multirow[b]{2}{*}{$\begin{array}{l}\text { Date con- } \\
\text { structed }\end{array}$} & \multirow[b]{2}{*}{$\begin{array}{l}\text { Reservoir } \\
\text { capacity }\end{array}$} & \multicolumn{4}{|c|}{ First sediment survey } & \multicolumn{4}{|c|}{ Second sediment survey } & \multicolumn{4}{|c|}{ Third sediment survey } & \multirow[b]{2}{*}{$\begin{array}{l}\text { Sediment yield between } \\
\text { construction \& last survey }\end{array}$} & \multirow[b]{2}{*}{$\begin{array}{l}\text { Loss of reser- } \\
\text { voir capacity }\end{array}$} \\
\hline & & & Date & $\begin{array}{l}\text { Volume of } \\
\text { sediment }\end{array}$ & $\begin{array}{l}\text { Volume. } \\
\text { weight }\end{array}$ & $\begin{array}{l}\text { Yield since } \\
\text { construction }\end{array}$ & Date & $\begin{array}{l}\text { Volume of } \\
\text { sediment }\end{array}$ & $\begin{array}{c}\text { Volume- } \\
\text { weight }\end{array}$ & $\begin{array}{l}\text { Yield since } \\
\text { last survey }\end{array}$ & Date & $\begin{array}{l}\text { Volume of } \\
\text { sediment }\end{array}$ & $\begin{array}{l}\text { Volume- } \\
\text { weight }\end{array}$ & $\begin{array}{l}\text { Yield since } \\
\text { last survey }\end{array}$ & & \\
\hline \multicolumn{17}{|c|}{ Medium-textured soils } \\
\hline W.I & $9 / 55$ & 41.1 & $5 / 60$ & 2.90 & 78 & 0.95 & $3 / 66$ & 2.90 & 82 & 0.04 & & & & & 0.44 & 0.16 \\
\hline W. 2 & $7 / 55$ & 13.0 & $8 / 58$ & 0.72 & 81 & 3.55 & $6 / 66$ & 0.76 & 77 & trace & & & & & 1.01 & 0.39 \\
\hline W. 3 & $9 / 54$ & 12.2 & $9 / 58$ & 0.00 & & 0.00 & $8 / 65$ & 0.00 & & 0.00 & & & & & 0.00 & 0.00 \\
\hline W4 & $9 / 54$ & 5.4 & $7 / 58$ & 0.04 & 77 & 0.15 & $8 / 66$ & 0.12 & 77 & 0.17 & & & & & 0.17 & 0.06 \\
\hline w.5 & $9 / 56$ & 280 & $8 / 58$ & 0.00 & & 000 & $7 / 65$ & $0 \mathrm{no}$ & & 0.00 & & & & & 0.00 & 0.00 \\
\hline W. 6 & $11 / 53$ & 10.5 & $7 / 58$ & 0.40 & 75 & 4.66 & $6 / 66$ & 0.40 & & 0.00 & & & & & 1.73 & 0.68 \\
\hline W-7 & $12 / 53$ & 22.6 & $5 / 60$ & 0.24 & 93 & 0.47 & $8 / 65$ & 0.24 & & 0.00 & & & & & 0.26 & 0.08 \\
\hline W-8 & $11 / 55$ & 26.9 & $7 / 58$ & 0.81 & 84 & 3.47 & $7 / 66$ & 1.56 & 84 & 1.07 & & & & & 1.67 & 0.58 \\
\hline W.9 & $11 / 51$ & 350.9 & $6 / 61$ & 16.90 & 84 & 3.61 & $6 / 69$ & 35.60 & 84 & 4.53 & & & & & 4.03 & 1.59 \\
\hline Average & & & & & & & & & & & & & & & 1.03 & 0.39 \\
\hline \multirow{2}{*}{\multicolumn{17}{|c|}{ Fine-textured soils }} \\
\hline W.10 & $10 / 56$ & 21.0 & $9 / 58$ & 2.36 & 60 & & & & & & & & & & & \\
\hline W.1I & $10 / 56$ & 12.2 & $9 / 58$ & 1.01 & 45 & 3.23 & $7 / 66$ & 5.75 & 46 & 3.81 & & & & & 3.69 & 2.36 \\
\hline$W .12$ & $10 / 56$ & 31.9 & $9 / 59$ & 2.27 & 52 & 9.79 & $12 / 62$ & 4.84 & 65 & 11.88 & $8 / 66$ & 5.44 & 65 & 2.45 & 7.74 & 3.93 \\
\hline$w \cdot 13$ & $8 / 56$ & 68.2 & $7 / 58$ & irace & 71 & Irace & $4 / 66$ & trace & 71 & trace & & & & & trace & 0.00 \\
\hline W. 14 & $11 / 56$ & 5.6 & $10 / 58$ & 0.46 & 70 & 10.45 & $12 / 62$ & 1.09 & 70 & 6.59 & $4 / 67$ & 1.24 & 70 & 1.51 & 5.19 & 2.35 \\
\hline W.15 & $11 / 54$ & 19.9 & $9 / 58$ & 1.59 & 70 & 5.50 & $1 / 63$ & 1.67 & 70 & 0.25 & $5 / 67$ & 1.77 & 70 & 0.31 & 1.88 & 0.79 \\
\hline Average & & & & & & & & & & & & & & & 3.47 & 1.74 \\
\hline
\end{tabular}

acre/year, ranged from 0 to 7.74 tons/ acre/year. This wide range of sediment yields emphasizes the fact that the watersheds have individual characteristics which must be considered when estimating sediment yield.

In general, the sediment yield values were greater between reservoir construction and the first survey than between the first and second surveys. Although these differences may be real, two other possibilities should be considered. First, the method used to obtain the original capacities of some reservoirs may have given misleading results; second, there may have been substantial erosion from the area disturbed by construction for a short time after construction.

Four watersheds on the mediumtextured soils show a sediment yield of more than 1 ton/acre/year between con- struction and the last survey; however, only two of these watersheds, W-8 and W-9, had sediment yields of more than 1 ton/acre/year at the second survey. Watersheds W-2, W-8, and W-9 have large percentages of steep slopes. All three watersheds have high percentages of shallow and thin breaks range site groups. Only watersheds W-8 and W-9 have small percentages of badlands range site group (included in miscellaneous).

All watersheds on fine-textured soils, except W-13, yielded sediment. W-13 is located in the transition zone between the medium-textured and fine-textured soils areas and, at higher elevations of the watersheds, the soils are derived from the Hell Creek and Fox Hills formation. Table 1 shows that of the fine-textured soils, watersheds W-13 had the highest total vegetal cover in 1960 . W-12 and $\mathrm{W}-14$ had the highest sediment yields.
W-12 has a high percentage of steep slopes and shallow range sites, and W-14 consists primarily of clayey range site with very poor vegetal cover. The four fine-textured soil watersheds that had the highest sediment yields also had the least vegetal cover in 1960. The high sediment yields from watersheds $\mathrm{W}-12$ and $\mathrm{W}-14$ during the dry period between 1958 and 1962, with the subsequent sediment decrease during the normal precipitation period 1962-1967, is another example of the vegetal cover effect on sediment yield.

A multiple linear regression anlalysis using all combinations of the independent variables was used to determine the relationship between four watershed characteristics and the average annual sediment yield(s) in tons/acre. The watershed characteristics are:

$A=$ vegetal cover in $1960 \mathrm{in} \mathrm{lb/acre}$

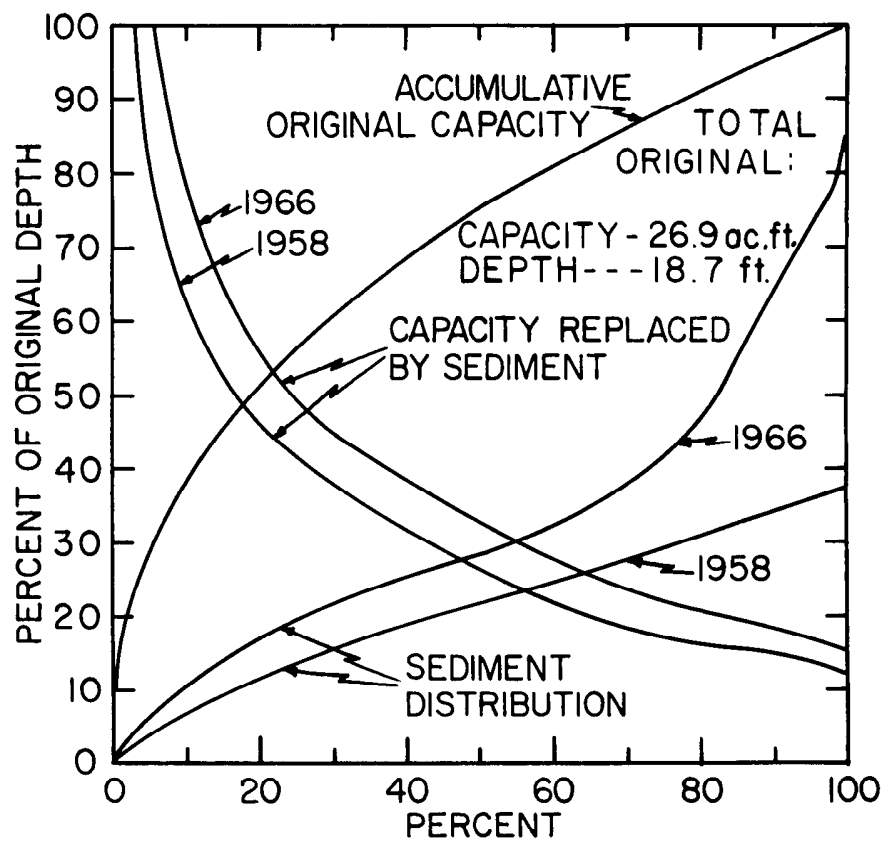

Fig. 3. Watershed 8 sedimentation information curves. (Medium-textured soils)

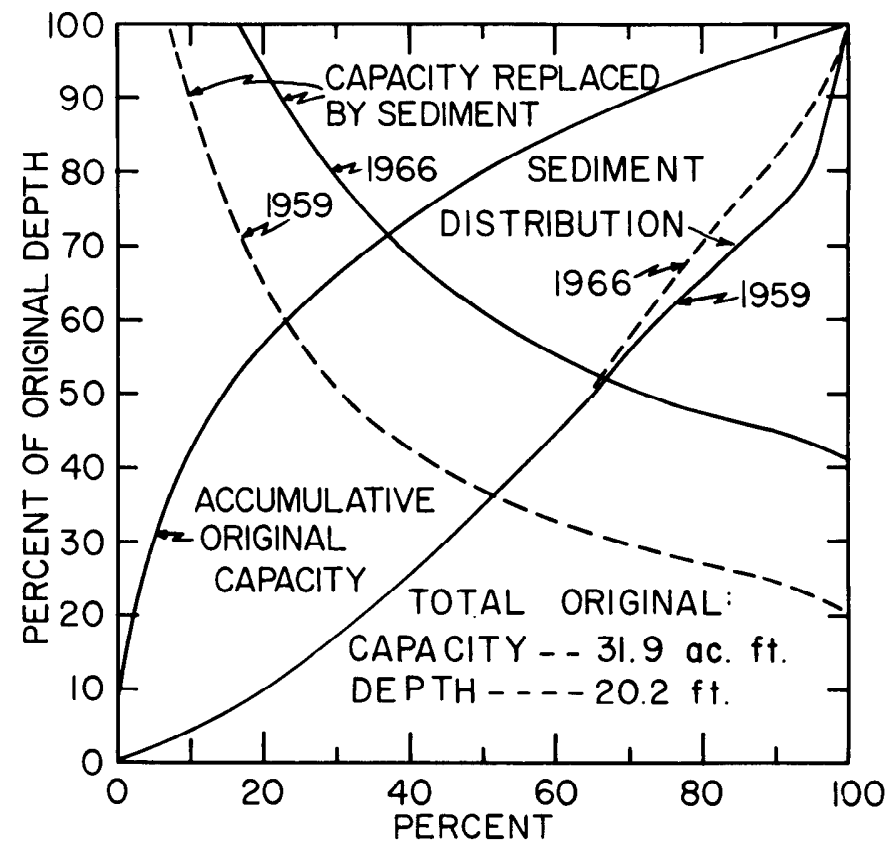

Fig. 4. Watershed 12 sedimentation information curves. (Fine-textured soils) 


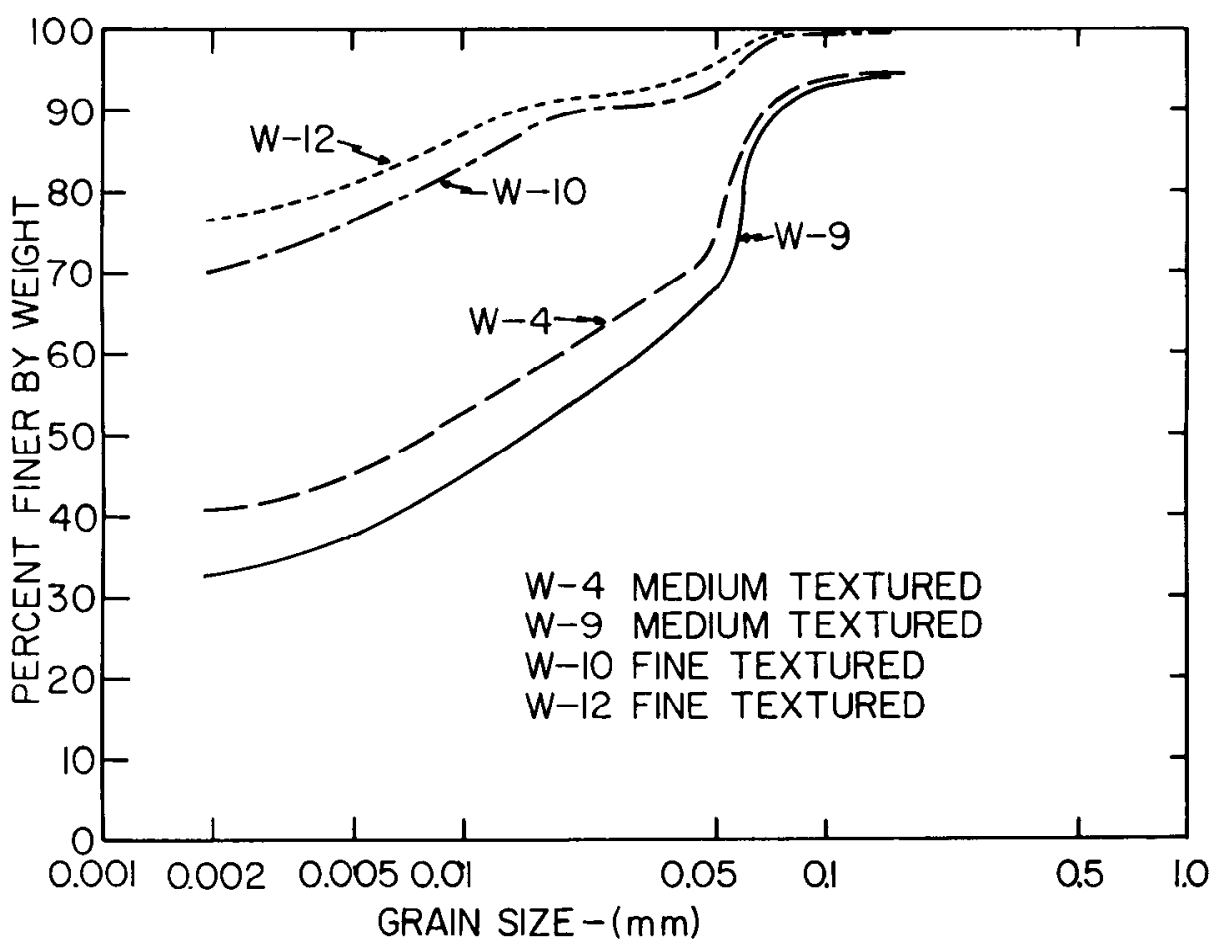

Fig. 5. Comparative grain size distribution curves of reservoir sediments from the two soil type watersheds.

$B=$ percentage of watershed area with a slope of $9 \%$ or greater

$\mathrm{C}=$ percentage of watershed area in shallow, thin breaks, clayey, dense clay, saline upland, and badlands range site groups

$\mathrm{D}=$ percentage of watershed areas in shallow, thin breaks, and badlands range site groups.

It was found that the average annual sediment yield was best expressed by the following equations:

$$
\begin{aligned}
& S=-0.752+0.021 B+0.038 C \\
& S=2.685-0.0011 A+0.049 D
\end{aligned}
$$

The coefficient of determination $\left(\mathrm{R}^{2}\right)$ for Equations 1 and 2 were 0.50 and 0.56 , respectively. The standard error of estimate was 1.73 and 1.63 for Equations 1 and 2. These equations can be used as a guide for estimating sediment yields from watersheds that have characteristics similar to watersheds used in this study. The choice of which equation to use will depend on the available watershed information.

The analysis also indicated that there was a negative relationship between $\mathrm{A}$ and $\mathrm{C}$, which shows that vegetal cover is related to the range site groups. There was a positive correlation between $B$ and $D$, indicating that the saline upland, shallow, and badlands range site groups are associated with the steeper slopes.

All reservoirs on fine-textured soils, except $\mathrm{W}-13$, spilled at some time during the study. Ilowever, they all have a very high capacity-watershed area ratio and, based on the curves presented by Brune (1953), the reservoirs have a trap efficiency greater than $92 \%$.

Sheet erosion has been the dominant sediment source in most watersheds listed in Table 1. Gully erosion is evident only on W-8 and W-9 of the medium-textured soils and on W-11 and W-12 of the fine soils. Stock water reservoirs are most frequently located on small upland tributaries where runoff is more infrequent and volumes are small; consequently, gullies do not develop, and sheet erosion is the major sediment source.

The sedimentation information curves, Figures 3 and 4, show that percentage of sediment accumulation is higher in the lower portions on the medium-textured reservoir, W-8, than in the fine-textured soil reservoir, W-12. In $1966,65 \%$ of the sediment was in the bottom $50 \%$ of W-12. The curves also show that in W-8 the bottom $16 \%$ of the reservoir is completely filled with sediment; in W-12 $42 \%$ is completely filled.

As would be expected, the sediment characteristics vary considerably between watershcds in the two soil textural groups. All sediment samples analyzed from the reservoirs of fine-textured soils were classified as clay; several samples had as much as $85 \%$ of the particles in the clay fraction of less than $0.002 \mathrm{~mm}$ (Fig. $5)$. The curves for the two reservoirs in the medium-textured soils show only about 32 to $40 \%$ of the particles in the less-than $-0.002 \mathrm{~mm}$ fraction. The textural classification of the samples analyzed from the reservoirs in the mediumtextured soil watersheds varied from clay and clay loam in the downstream half of the reservoir to sandy clay loam in the headwater portion.

The volume-weight of sediment deposited in the reservoirs on the watersheds having medium-textured soils averaged $81 \mathrm{lb} / \mathrm{ft}^{3}$; an average of $62 \mathrm{lb} / \mathrm{ft}^{3}$ was measured in reservoirs on watersheds having fine-textured soils. Data from individual sampling sites showed, in all cases, increases in sediment volumeweight with increased sediment depth.

If there is sufficient runoff to justify construction of a stock water reservoir, sediment will be deposited in the reservoir and must be considered in the reservoir design. The losses in reservoir capacity for the reservoirs under study, as shown in Table 2 and Equations 1 and 2, can serve as guides in future designs.

Annual sediment accumulation rates (loss of reservoir capacity) from watersheds in the fine-textured soils averaged about 1.7 acre-feet/square mile, whereas the annual accumulation from the soils of the medium-textured watersheds was only about 0.4 acre-foot/square mile. In general, this means that the useful life of reservoirs on watersheds with mediumtextured soils is about four times longer than for reservoirs on watersheds with fine-textured soils. The low sediment accumulation rates from the mediumtextured soils watersheds are similar to the rates of most reservoirs studied by Dendy et al, (1971). Of the 1,105 reservoirs studied by these men, $65 \%$ had sediment accumulation of less than 1 acre-foot/square mile per year.

\section{Summary}

Reservoir sedimentation studies were made between 1958 and 1969 on stock water reservoirs to determine sediment yields from rangeland watersheds on two soil textural groups of western South Dakota.

Data from 15 experimental watersheds indicate that the Inlean annual sediment yields are related to the soil textural groups. Watersheds having fine-textured soils show a mean annual sediment yield of 3.47 tons/acre, while watersheds with medium-textured soils had a mean annual sediment yield of 1.03 tons/acre. 
Analysis of sediment samples from the watersheds with fine-textured soil shows that the textural classification of all samples was clay; the average volumeweight was about $62 \mathrm{lb} / \mathrm{ft}^{3}$. Samples from the watersheds with medium-textured soils ranged from clay to clay loam within the downstream half of the reservoirs to sandy loam within headwater portions of the reservoirs; the average volume-weight was $81 \mathrm{lb} / \mathrm{ft}^{3}$.

\section{Literature Cited}

Brune, Gunnar M. 1953. Trap efficiency of reservoirs. Trans. Amer. Geophys. Union, $34: 407-418$.

Dendy, F. E., W. A. Champion, and R. B. Wilson. 1971. Reservoir sedimentation surveys in the United States. Proc. of the Int. Symp. on Man-Man Lakes, May 1971, Knoxville, Tenn.

Dyksterhuis, E. J. 1949. Condition and management of rangeland based on quantitative ecology. J. Range Manage., 2:104-115.

Gottschalk, L. C. 1952. Measurement of sedimentation in small reservoirs. Trans. Amer. Soc. Civil Eng., 117:59-71.

Heinemann, H. G., and V. I. Dvorak. 1965. Improved volumetric survey and computation procedures for small reservoirs. Proc. of the Federal Inter-Agency Sedimentation Conference, 1963. U. S. Dep. Agr. Misc. Pub. 970.

Hershfield, David M. 1961. Rainfall frequency atlas of the United States for durations from 30 minutes to 24 hours and return periods from 1 to 100 years. U. S. Dep. Com., U.S. Weather Bureau Tech. Paper No. 40.115 p.

Spuhler, Walter, W. F. Lytle, and Dennis Moe. 1968. Climatological Summary No. 10, Climatography of the U.S., No. 20-39, from U.S. Weather Bureau Records.

U. S. Dep. Agr. 1970. Butte County, South Dakota, Soil Survey. Soil Conser. Serv. (unpublished). 